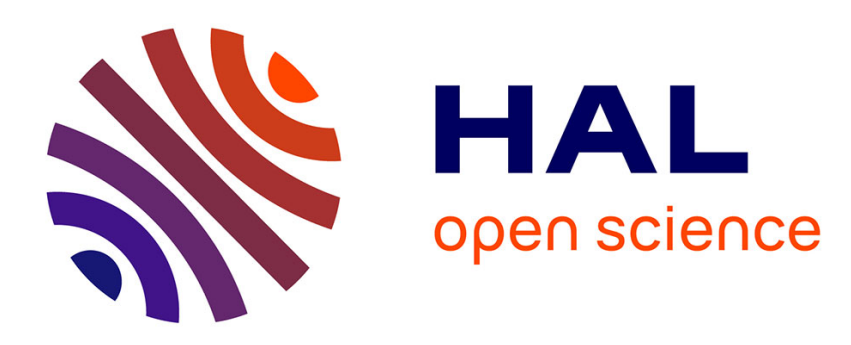

\title{
Molecular detection of Nosema ceranae and N. apis from Turkish honey bees
}

\author{
Justin Whitaker, Allen Szalanski, Meral Kence
}

\section{To cite this version:}

Justin Whitaker, Allen Szalanski, Meral Kence. Molecular detection of Nosema ceranae and N. apis from Turkish honey bees. Apidologie, 2011, 42 (2), pp.174-180. 10.1051/apido/2010045 . hal01003579

\section{HAL Id: hal-01003579 \\ https://hal.science/hal-01003579}

Submitted on 1 Jan 2011

HAL is a multi-disciplinary open access archive for the deposit and dissemination of scientific research documents, whether they are published or not. The documents may come from teaching and research institutions in France or abroad, or from public or private research centers.
L'archive ouverte pluridisciplinaire HAL, est destinée au dépôt et à la diffusion de documents scientifiques de niveau recherche, publiés ou non, émanant des établissements d'enseignement et de recherche français ou étrangers, des laboratoires publics ou privés. 


\title{
Molecular detection of Nosema ceranae and $N$. apis from Turkish honey bees*
}

\author{
Justin WhitaKeR ${ }^{1}$, Allen L. SzALANSKI ${ }^{1}$, Meral KenCE ${ }^{2}$ \\ ${ }^{1}$ Insect Genetics Lab, Department of Entomology, University of Arkansas, Fayetteville, Arkansas 72701, USA \\ ${ }^{2}$ Department of Biology, Middle East Technical University, Ankara 06531, Turkey
}

Received 7 January 2010 - Revised 28 April 2010 - Accepted 29 April 2010

\begin{abstract}
Polymerase chain reaction specific for the rDNA marker for Nosema ceranae and Nosema apis was conducted on 84 Apis mellifera samples collected from 20 provinces in Turkey. N. ceranae was detected from three samples from the provinces of Artvin, Hatay, and Muğla. N. apis was detected in samples from the provinces of Sivas, Izmir, Bitlis and Gaziantep. All of the positive samples were from honey bees belonging to the ' $C$ ' lineage of $A$. mellifera. DNA sequencing analysis of the $N$. ceranae samples revealed that there was no intraspecific variation in the 208 bp of the 16S SSU of N. ceranae from Turkey. A TCS analysis revealed that the 16S SSU genotype from Turkey is identical to $N$. ceranae DNA sequences from Europe, Australia, and the United States. TCS analysis also revealed that this genotype is the basal ancestral genotype among six $N$. ceranae genotypes. This is the first study to confirm that $N$. ceranae is present in honey bees from Turkey.
\end{abstract}

Apis mellifera / Nosema ceranae / Nosema apis / molecular diagnostics / Turkey

\section{INTRODUCTION}

The microsporidia species Nosema apis and $N$. ceranae cause a destructive disease of honey bees, Apis mellifera L., worldwide (Bailey, 1991; Higes et al., 2006; Huang et al., 2007). Nosema affects adults only, infecting epithelial cells lining the midgut. Nosema often escapes notice due to its frequent lack of outward symptoms. The organism can cause digestive disorders, shorten bee life spans, reduce pollen collection, induce queen supercedure, decrease colony population, reduce honey production, and cause greater colony mortality in the winter. Efforts to control Nosema include removing older combs and treating hives with fumagillan. $\mathrm{Ob}-$ servations indicate that Nosema is distributed by mailing and transportation of honey bees

Corresponding author: A. Szalanski, aszalan@uark.edu

* Manuscript editor: Klaus Hartfelder
(Jay, 1966) and infective beekeeping materials (Klee et al., 2007) combined with migratory beekeeping practices (Giersch et al., 2009). Environmental reservoirs and non-honey bee vectors of Nosema spores may contribute to its epidemiology. For example, the range of the migratory bee-eating bird Merops apiaster includes Western Asia, and its regurgitated pellets have been shown to contain infective Nosema spores (Higes et al., 2008a). In 1913, Fantham and Porter demonstrated that $N$. apis is capable of infecting other insect species, though some of their results have been called into question through subsequent experiments (Bailey, 1991).

Recently an illness of A. mellifera, called "Colony Collapse Disorder" (CCD) or "Colony Loss" has been causing large-scale losses of honey bees in the United States (Chen et al., 2007) and in Europe (Topolska et al., 2008; Higes et al., 2008b). A possible contributor to CCD may be $N$. ceranae, a species of Nosema from Apis cerana that has 


\section{$123 \mathrm{bp}$}

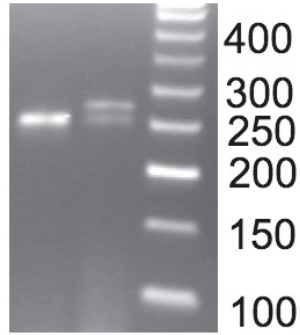

Figure 1. PCR products of $N$. ceranae and $N$. apis: Lane 1: N. ceranae positive sample; Lane 2: N. apis (269 bp) and $N$. ceranae (250 bp) control; Lane 3: 50 bp DNA ladder.

been recently found in $A$. mellifera (Higes et al., 2006; Topolska et al., 2008; Vejsnaes et al., 2010; Paxton, 2010). Recent studies by Chauzat et al. (2007), Williams et al. (2008), Klee et al. (2007), Martín-Hernández et al. (2007), Paxton et al. (2007), Higes et al. (2009), Tapaszti et al. (2009), and Giersch et al. (2009) have revealed that $N$. ceranae is widespread in Africa, Europe, Australia, and North America. To date, N. ceranae has not been observed in Turkey. A previous study by Aydin et al. (2005) identified the presence of $N$. apis in honey bees from Turkey. However, this study did not attempt to distinguish $N$. apis from $N$. ceranae using molecular diagnostic methods.

The objectives of this study were to detect $N$. ceranae and $N$. apis from Turkish honey bees using PCR and to determine the genetic relationship of $N$. ceranae from Turkey relative to $N$. ceranae from other countries.

\section{MATERIALS AND METHODS}

\subsection{Sample collection}

Samples were collected by one of the authors (M.K.) from beekeepers in 2005 and 2006 from 20 provinces in Turkey (Tab. I). Five to 20 worker honey bees were placed in a plastic liquid scintillation vial containing $70 \%$ ethanol.

\subsection{DNA extraction}

The Puregene DNA extraction kit (Gentra, Minneapolis, MN) was used to obtain DNA from honey bee abdomens using a procedure similar to Magnus and Szalanski (2010). Abdomens from two bees from each sample were allowed to air dry before adding the samples to cell lysis buffer. Extracted DNA was resuspended in 50 ul of Tris: EDTA buffer (pH 8.0), and stored at $-20^{\circ} \mathrm{C}$ until PCR.

\subsection{PCR amplification}

Polymerase chain reaction specific for the rRNA marker for $N$. ceranae and $N$. apis was conducted using the primers $N$. ceranae $\mathrm{F}$ and $N$. ceranae $\mathrm{R}$ and $N$. apis sense and antisense per Chen et al. (2008, 2009). These primers were used together for a multiplex PCR reaction and resulted in a $250 \mathrm{bp}$ amplicon of the small subunit (16S) ribosomal RNA gene for $N$. ceranae and a 269 bp amplicon for $N$. apis (Fig. 1). Positive controls consisted of $N$. ceranae from honey bees collected from Nebraska, USA, and N. apis from honey bees collected from Beaverlodge, Alberta, Canada. In addition, a negative control was included for most PCR runs. For PCR $2 \mu \mathrm{L}$ of DNA template was used for the $50 \mu \mathrm{L}$ multiplex PCR. Concentration of reagents, other than PCR primers, is provided in Szalanski and McKern (2007). The PCR thermocycler profile consisted of 40 cycles of a $94{ }^{\circ} \mathrm{C}$ for $45 \mathrm{~s}, 58^{\circ} \mathrm{C}$ for $45 \mathrm{~s}$, and $72{ }^{\circ} \mathrm{C}$ for $60 \mathrm{~s}$, with a final extension of $5 \mathrm{~min}$ at $72{ }^{\circ} \mathrm{C}$. Amplicons were run on a $2 \%$ agarose gel electrophoresis, and products were visualized under UV.

\subsection{DNA sequencing}

Three positive $N$. ceranae PCR samples were subjected to DNA sequencing. For these samples a $208 \mathrm{bp}$ region of the $16 \mathrm{~S}$ gene was subjected to $\mathrm{PCR}$ using the primers Nosema F/Nosema $\mathrm{R}$ (Chen et al., 2008) using the thermocycler profile outlined above. Once PCR products were purified using Microcon-PCR Filter Units (Millipore, Bedford, MA), they were sent to the University of Arkansas Medical Sciences DNA Sequencing Core Facility (Little Rock, AR) for direct sequencing in both directions. CLUSTAL W (Thompson et al., 1994) and Bioedit v5.0.7 software (Hall, 1999) were used to align DNA sequences. 
Table I. Prevalence of N. ceranae and N. apis in different regions of Turkey.

\begin{tabular}{llcc}
\hline Region (n) & Province (n) & N. ceranae & N. apis \\
\hline Marmara (42) & Gökçeada (6) & 0 & 0 \\
& Kirklareli (5) & 0 & 0 \\
& Bursa (15) & 0 & 0 \\
& Sakarya (16) & 0 & 0 \\
Aegean (4) & Izmir (2) & 0 & 1 \\
& Muğla (2) & 1 & 0 \\
Black Sea (15) & Düzce (2) & 0 & 0 \\
& Giresun (5) & 0 & 0 \\
Central Anatolia (3) & Artvin (8) & 1 & 0 \\
\multirow{3}{*}{ South East Anatolia (11) } & Ankara (1) & 0 & 0 \\
& Sivas (2) & 0 & 1 \\
& Gaziantep (2) & 0 & 1 \\
& Adiyaman (2) & 0 & 0 \\
& Diyarkakir (3) & 0 & 0 \\
& Batman (1) & 0 & 1 \\
& Bitlis (2) & 0 & 0 \\
Medditerranean (7) & Sirnak (1) & 0 & 0 \\
Eastern Anatolia (2) & Hatay (7) & 1 & 0 \\
& Erzincan (1) & 0 & 0 \\
\hline
\end{tabular}

A BLAST search (http://blast.ncbi.nlm.nih.gov) was used to compare genetic variation of the 208 bp amplicons from Turkey with those available on GenBank. Genealogy of $N$. ceranae $16 \mathrm{~S}$ genotypes from our lab and from GenBank was determined using the method of Templeton et al. (1992), which represent the evolutionary steps between genotypes, using TCS v 1.21 (Clement et al., 2000).

\section{RESULTS}

From the 84 samples subjected to PCR analysis, $N$. ceranae was amplified one time in each from samples from the provinces of Artvin, Hatay, and Muğla (Tab. I, Fig. 2). Nosema apis was detected one time each from the provinces of Sivas, Izmir, Bitlis and Gaziantep (Tab. I, Fig. 2). These positive samples were from beekeepers located at widely dispersed geographical regions in Turkey, including the Aegean, Mediterranean, South East Anatolia, Central Anatolia, and the Black Sea. The only region we found to have A. mellifera positive for both $N$. apis and $N$. ceranae infection was the Aegean region.

From the three positive $N$. ceranae samples from Turkey, no intraspecific DNA sequence variation was observed among the $208 \mathrm{bp} 16 \mathrm{~S}$ sequences. Using the $N$. ceranae $16 \mathrm{~S}$ DNA sequences available on GenBank, a total of 6 different genotypes, designated as genotypes G1G6, were found using the same 208 bp region used in this study (Tab. II, Fig. 3). A BLAST search revealed that the $N$. ceranae DNA 208 bp sequence from Turkey, designated as genotype 2 (G2), was identical to N. ceranae DNA sequences from the United States, Europe, and Australia. TCS spanning network of the $N$. ceranae genotypes revealed that genotype $\mathrm{G} 2$ was the basal type, which was one base pair different with other genotypes, except for G3 and G6 (Fig. 3). Genotype G2 can be considered as the basal ancestral genotype because it is located at the base of the genealogy. Genotype $\mathrm{G} 3$ was the most distantly related to $\mathrm{G} 2$, with three base pair differences, and only occurred in Australia (GenBank accession number FJ789791).

\section{DISCUSSION}

This study demonstrated that both $N$. apis and $N$. ceranae are present in honey bees 


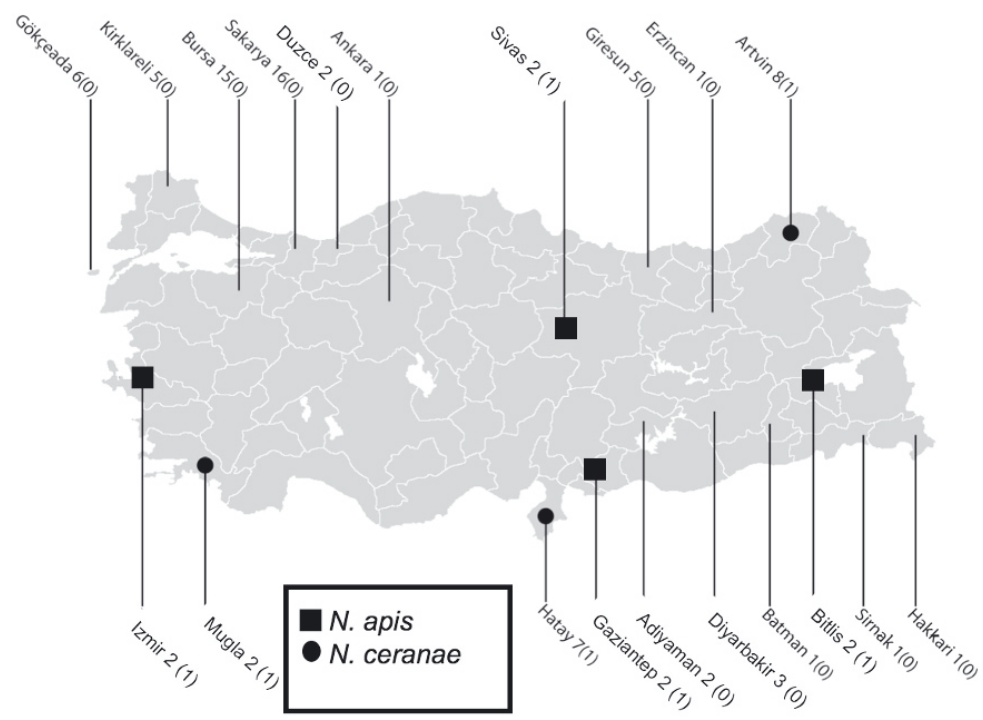

Figure 2. Map of Turkey showing provinces from which A. mellifera were collected and tested for $N$. ceranae and $N$. apis. The number of samples screened is provided along with the numbers positive for $N$. ceranae and $N$. apis, respectively, in parentheses.

Table II. Mitochondrial DNA haplotypes of Nosema ceranae using a 208 bp region of the rDNA 16S gene.

\begin{tabular}{llcc}
\hline Haplotype & Location & $\begin{array}{c}\text { GenBank } \\
\text { Accession Number }\end{array}$ & Source \\
\hline G1 & Unknown & U26533 & Fries et al. (1996) \\
& Korea & FJ481912 & Unpublished \\
G2 & Switzerland & DQ673615 & Unpublished \\
& Australia & FJ789797 & Unpublished \\
& Turkey & - & This Study \\
& USA & - & JW unpublished \\
& Austria & EU045844 & Unpublished \\
& France & DQ374655 & Unpublished \\
& Germany & DQ374656 & Martín-Hernández et al. (2007) \\
G3 & Australia & FJ789791 & Unpublished \\
G4 & Argentina & EU025027 & Unpublished \\
G5 & Australia & FJ789795 & Unpublished \\
G6 & Taiwan & DQ486028 & Unpublished \\
\hline
\end{tabular}

from the Republic of Turkey. N. ceranae was observed in geographically distant regions of Turkey, including the Aegean, Mediterranean and Black Sea. Aydin et al. (2005) found Nosema sp. from six regions in Turkey, with the majority occurring in Marmara and the Black Sea. We did not find N. apis or N. ceranae in Marmara, Central Anatolia, or East Anatolia, but we did find it in Southeast Anatolia, a region where Nosema sp. was not detected by Aydin et al. (2005).
Our finding of three positive $N$. ceranae samples out of $84(3.6 \%)$ is on the low end of the spectrum, relative to the frequency of $N$. ceranae $(65.6 \%)$ in samples from France in 2002-2005 (Chauzat et al., 2007), Minnesota in the United States (40\%), three Canadian provinces (19.6\%) (Williams et al., 2008), and in Australia in 2008 (4.5-33.7\%) (Giersch et al., 2009). This number is provided for comparison only and should be interpreted with caution. The goal of our study was only to 


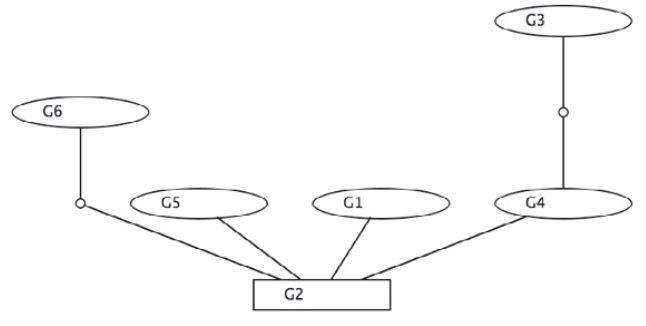

Figure 3. Genealogical relationships among $16 \mathrm{~S}$ genotypes of Nosema ceranae estimated by TCS (Clement et al. 2000). A unit branch represents one mutation and small ovals indicate genotypes that were not observed.

detect the presence or absence of $N$. ceranae and $N$. apis in Turkey. Our sample size of 2 bees per colony is insufficient to provide a statistically significant measurement of Nosema prevalence.

Some of the Turkish provinces are overrepresented as compared to others, but the samples are representative of a wide number of subclimates and are from locations spanning the entire country. Samples used for our $N$. apis, $N$. ceranae PCR study were previously used for a population genetics study of A. mellifera in Turkey (Solorzano et al., 2009). The $N$. ceranae positive honey bee samples belonged to mtDNA COI-COII ' $\mathrm{C}$ ' lineage mitotypes, $\mathrm{C} 11$ (Artvin), and $\mathrm{C} 12$ (Hatay and Muğla), and the N. apis positive samples belonged to the mitotypes C12 (Izmir and Bitlis), C13 (Sivas) and C19 (Gaziantep). To our knowledge, no other studies on molecular detection of $N$. ceranae or $N$. apis have documented the genetic lineage or mitotype of the host bees, so the relationship of $N$. ceranae infection and different host lineages is unknown. All of the three provinces (Artvin, Hatay, and Muğla) where N. cerenae were detected also showed high rates of colony losses in 2006/2007 (Giray et al., 2010). For Artvin province, $50 \%$ of 2505 colonies maintained by 44 beekeepers were lost, while $39.4 \%$ of 7628 colonies maintained by 36 beekeepers in Hatay province were lost, and $22.7 \%$ of 6516 colonies maintained by 36 beekeepers were lost in Muğla province. Though the cause of the colony losses cannot be conclusively attributed to $N$. ceranae infection, there exists a potentially significant relationship between its presence and the occurrence of the losses. Similar colony loss reports that may be attributed to $N$. ceranae have been documented in Poland (Topolska et al., 2008) and Denmark (Vejsnaes et al., 2010).

The high level of genetic similarity of $16 \mathrm{~S}$ rDNA sequences of $N$. ceranae from Turkey relative to those found elsewhere complicates efforts to determine a geographic origin for $N$. ceranae, as well as efforts to identify strains with varying degrees of virulence. DNA sequencing analysis of a larger region of $16 \mathrm{~S}$ rDNA, or the use of additional genetic markers may provide additional insight. It is perhaps not surprising that $N$. ceranae should be found in Turkey, as it is close to the native range of the original host of $N$. ceranae, the Asiatic honey bee A. cerana F., which is found from Western Afghanistan to Japan (Dietz, 1992). The minor variation found between strains of $N$. ceranae encourages shifts in future emphases on research from finding differences in parasitic virulence perhaps to evaluating different $N$. ceranae genes for variation and to finding differences in honey bee lineage susceptibility, and examining climatic and environmental variables involved in $N$. ceranae prevalence and transmission. It may be that certain bee lineages are more or less able to cope with $N$. ceranae infection, or simply that an increase in their genetic diversity through breeding programs or interbreeding with feral "survivor" populations will provide them with more mechanisms to adapt. In addition, the potential role of climatic and environmental variables should not be ignored.

\section{ACKNOWLEDGEMENTS}

The authors would like to express their gratitude to the Ministry of Agriculture and Rural Affairs of Turkey, beekeepers and colleagues for their assistance in the collection of honey bee specimens in Turkey and Ray Fisher at the University of Arkansas for Adobe Illustrator assistance. This research was supported in part by the University of Arkansas, Arkansas Agricultural Experiment Station, TUBITAK and the Middle East Technical University, Ankara, Turkey. 
Détection moléculaire de Nosema ceranae et $N$. apis chez des abeilles de Turquie.

\section{Diagonostic moléculaire / Turquie / Apis melli- fera / Nosema ceranae / Nosema apis}

\section{Zusammenfassung - Molekulare Detektion von Nosema ceranae und $N$. apis in Honigbienen aus} der Türkei. Das Mikrosporidium Nosema ceranae verursacht weltweit eine ernsthafte Krankheit der Honigbiene Apis mellifera L. (Higes et al., 2006). Eine vor kurzem aufgetretene Krankheit unter der Bezeichnung „Colony Collapse Disorder“ (CCD) oder „Völkerverlust“ führt ebenfalls zu hohen Verlusten bei Honigbienen in den Vereinigten Staaten (Chen et al., 2007) und in Europa (Higes et al., 2008b). Als ein möglicher Mitverursacher der CCD kommt $N$. ceranae in Frage, eine Nosema-Art von Apis cerana, die vor kurzem auch bei A. mellifera nachgewiesen wurde (Higes et al., 2006). Über das Vorkommen von $N$. ceranae in der Türkei gab es bisher noch keine Berichte. Eine frühere Studie von Aydin et al. (2005) lieferte allerdings Hinweise auf das Vorkommen von $N$. apis in türkischen Honigbienen. Diese Studie wurde jedoch nicht mit molekularen Diagnostikmethoden durchgeführt, die eine Unterscheidung von $N$. apis und $N$. ceranae erlaubt hätten. Ziel der vorliegenden Studie war es deshalb, zum einen das Vorkommen von $N$. ceranae und $N$. apis in türkischen Honigbienen mittels einer Polymerasekettenreaktions(PCR)-Methode zu überprüfen und andererseits $N$. ceranae aus der Türkei mit $N$. ceranae aus anderen Ländern genetisch $\mathrm{zu}$ vergleichen.

Hierzu wurde DNA aus Abdomina von Bienen mittels einer auf der von Magnus und Szalanski (2010) entwickelten Methode extrahiert. Für PCRAnalysen von N. ceranae- und N. apis-spezifischen rRNA Markern bei 84 Apis mellifera Proben aus 20 Provinzen der Türkei (Abb. 1 und 2) benutzten wir die von Chen et al. $(2008,2009)$ entwickelten Primer $N$. ceranae $\mathrm{F}$ und $N$. ceranae $\mathrm{R}$, sowie $N$. apis sense und antisense. Damit konnten wir Nosema ceranae in drei Proben aus den Provinzen Artvin, Hatay und Muğla, und N. apis in Proben aus den Provinzen Sivas, Izmir, Bitlis and Gaziantep nachweisen (Tab. I). Alle positiven Honigbienenproben konnten der ' $\mathrm{C}$ ' Linie von A. mellifera zugeordnet werden. DNA-Sequenzierungsanalysen von $N$. ceranae Proben zeigten keine genetische Variabilität in dem 208 bp Fragment der kleinen Untereinheit (SSU) der 16S RNA von $N$. ceranae aus der Türkei. Und in einer TCS und BLAST-Analyse erwies sich der 16S SSU Genotyp aus der Türkei als identisch mit $N$. ceranae DNA-Sequenzen aus Europa, Australien und den USA (Abb. 3). Die TCSAnalyse zeigte auch, dass es sich hierbei um den basalen, urspünglichen Genotyp innerhalb der sechs $N$. ceranae Genotypen handelt.

In dieser Untersuchung konnten wir zeigen, dass sowohl $N$. apis als auch $N$. ceranae in Honigbienen aus der Türkei vorkommen. $N$. ceranae war bisher in geographisch entlegenen Gebieten der Türkei, sowie in Regionen der Ägäis, des Mittelmeers und des Schwarzen Meeres nachgewiesen worden. Aydin et al. (2005) fanden Nosema sp. in sechs Regionen der Türkei, und hier überwiegend in Marmara- und Schwarzmeergebieten. Wir konnten zwar keine $N$. apis- oder $N$. ceranae-Vorkommen in Marmara, Zentral- oder Ostanatolien nachweisen, jedoch aber in Südostanatolien, einer Region in der Aydin et al. (2005) keine Nosema sp. gefunden hatten. Aufgrund der geringen genetischen Variabilität zwischen $N$. ceranae-Linien schlagen wir vor, dass künftige Forschungsprojekte sich weniger auf die Untersuchung genetischer Unterschiede in der Virulenz, sondern vielmehr auf die Untersuchung spezifischer $N$. ceranae Virulenzgene konzentrieren sollten, sowie auf Gene, die bei Honigbienen eine Rolle in der Nosema-Suszeptibilität spielen könnten. Hierzu sollten auch klimatische Variablen und andere Umgebungsbedinungen in Betracht gezogen werden, die für die Prävalenz und Übertragung von $N$. ceranae von Bedeutung sein können. Daneben kann es durchaus sein, dass bestimmte Bienenlinien mit $N$. ceranae-Infektionen besser zurechtkommen als andere, oder dass einfach eine erhöhte genetische Variabilität durch Zuchtprogramme und Einkreuzung wilder Populationen, die die Krankeit überlebt hatten, es erlauben könnte, dass Bienen adaptive Mechanismen im Umgang mit der Krankheit entwickeln.

Apis mellifera / Nosema ceranae / Nosema apis / molekulare Diagnostik / Türkei

\section{REFERENCES}

Aydin L., Cakmak I., Gulegen E., Wells, H. (2005) Honey bee Nosema disease in the Republic of Turkey, J. Apic. Res. 44, 196-197.

Bailey L., Ball B.V. (1991) Honey bee pathology, Academic Press, London.

Chauzat M.-P., Higes M., Martin-Hernandez R., Meana A., Cougoule N., Faucon J.P. (2007) Presence of Nosema ceranae in French honey bee colonies, Apidologie 46, 127-128.

Chen Y., Evans J.D., Smith I.B., Pettis J.S. (2008) Nosema ceranae is a long-present and widespread microsporidian infection of the European honey bee (Apis mellifera) in the United States, J. Invertebr. Pathol. 97, 186-188.

Chen Y., Evans J.D., Zhou L., Boncristiani H., Kimura K., Xiao T., Litkowski A.M., Pettis J.S. (2009) Asymmetrical coexistence of Nosema ceranae and Nosema apis in honey bees, J. Invertebr. Pathol. 101, 204-209. 
Clement M., Posada D., Crandall K.A. (2000) TCS: a computer program to estimate gene genealogies, Mol. Ecol. 9, 1657-1660.

Dietz A. (1992) Honey bees of the world, The Hive and the Honey Bee, in: Graham J.M. (Ed.), Dadant and Sons, Hamilton, IL. pp. 23-71.

Fries I.M., Feng F., da Silva A.J., Slemenda S.B., Pieniazek N.J. (1996) Nosema ceranae n. sp. (Microsporidia, Nosematidae), morphological and molecular characterization of a microsporidian parasite of the Asian honey bee Apis cerana (Hymenoptera, Apidae), Eur. J. Protistol. 32, 356365.

Giersch T., Berg T., Galea F., Hornitzky, M. (2009) Nosema ceranae infects honey bees (Apis mellifera) and contaminates honey in Australia, Apidologie 40, 117-123.

Giray T., Kence M. Oskay D., Döke M.A., Kence A. (2010) Colony losses in Turkey and causes of bee deaths, Apidologie 41, in press.

Hall T.A. (1999) BioEdit: a user-friendly biological sequence alignment editor and analysis program for Windows 95/98/NT, Nucleic Acids Symp. Ser. 41, 95-98.

Higes M., Martin R., Meana A. (2006) Nosema ceranae, a new microsporidian parasite in honey bees in Europe, J. Invertebr. Pathol. 92, 93-95.

Higes M., Martín-Hernández R., Garrido-Bailón E., Botías C., García-Palencia P., Meana A. (2008a) Regurgitated pellets of Merops apiaster as fomites of infective Nosema ceranae (Microsporidia) spores, Environ. Microbiol. 10, 1374-1379.

Higes M., Martin-Hernandez R., Botias C., Bailon E.G., Gonzalez-Porto A.V., Barrios L., Jesus del Nozal M., Bernal J.L., Jimenez, J.J., Palencia P.G., Meana A. (2008b) How natural infection by Nosema ceranae causes honeybee colony collapse, Environ. Microbiol. 10, 2659-2669.

Higes M., Martín-Hernández R., Garrido-Bailón E., Botías C., Meana A. (2009) First detection of Nosema ceranae (Microsporidia) in African Honey bees (Apis mellifera intermissa), J. Apic. Res. 48, 217-219.

Huang W.F., Jiang J.H., Chen Y.W., Wang C.H. (2007) A Nosema ceranae isolate from the honeybee Apis mellifera, Apidologie 38, 1-8.

Jay S.C. (1966) A survey of Nosema disease in package bees, queens and attendant bees entering Manitoba (1963-1966), Proc. Entomol. Soc. Manitoba 22, 61-64.

Klee J., Besana A.M., Genersch E., Gisder S., Nanetti A., Tam D.Q., Chinh T.X., Puerta F., Ruz J.M., Kryger P., Message D., Hatjina F., Korpela S., Fries I., Paxton R.J. (2007) Widespread dispersal of the microsporidian Nosema ceranae, an emergent pathogen of the western honey bee, Apis mellifera, J. Invertebr. Pathol. 96, 1-10.

Magnus R.M., Szalanski A.L. (2010) Genetic evidence of honey bees belonging to the Middle East lineage in the United States, Sociobiology 55, 285296.

Martín-Hernández R., Meana A., Prieto L., Salvador A.M., Garrido-Bailon E., Higes M. (2007) Outcome of colonization of Apis mellifera by Nosema ceranae, Appl. Environ. Microbiol. 73, 6331-6338.

Paxton R.J. (2010) Does infection by Nosema ceranae cause "Colony Collapse Disorder" in honey bees (Apis mellifera), J. Apic. Res. 49, 80-84.

Paxton R.J., Klee J., Korpela S., Fries I. (2007) Nosema ceranae has infected Apis mellifera in Europe since at least 1998 and may be more virulent than Nosema apis, Apidologie 38, 558-565.

Solorzano C.D., Szalanski A.L., Kence M., McKern J.A., Austin J.W., Kence A. (2009) Phylogeography and population genetics of honey bees (Apis mellifera L.) from Turkey based on COI-COII sequence data, Sociobiology 53, 237-246.

Szalanski A.L., McKern J.A. (2007) Multiplex PCRRFLP diagnostics of the Africanized honey bee (Hymenoptera: Apidae), Sociobiology 50, 939_ 945 .

Tapaszti Z., Forgách P., Kövágó C., Békési L., Bakonyi T., Rusvai M. (2009) First detection and dominance of Nosema ceranae in Hungarian honeybee colonies, Acta Vet. Hung. 57, 383-388.

Templeton A.R., Crandall K.A., Sing, C.F. (1992) A cladistic analysis of phenotypic associations with haplotypes inferred from restriction endonuclease mapping and DNA sequence data. III. Cladogram estimation, Genetics 132, 619-633.

Thompson J.D., Higgins D.G., Gibson T.J. (1994) CLUSTAL W: improving the sensitivity of progressive multiple sequence alignments through sequence weighting, position-specific gap penalties and weight matrix choice, Nucleic Acids Res. 22, 4673-4680.

Topolska G., Gajda A., Hartwig A. (2008) Polish honey bee colony-loss during the winter of 2007/2008, J. Apic. Sci. 52, 95-104.

Williams G.R., Shafer A.B.A., Rogers R.E.L., Shutler D., Stewart D.T. (2008) First detection of Nosema ceranae, a microsporidian parasite of European honey bees (Apis mellifera), in Canada and central USA, J. Invertebr. Pathol. 97, 189-192.

Vejsnaes F., Neilson S.L., Kryger P. (2010) Factors involved in the recent increase in colony loss in Denmark, J. Apic. Res. 49, 109-110. 